\title{
Scala Conflict Muncă-Familie: Analiza proprietăţilor psihometrice ale versiunii în limba română
}

\author{
Coralia Sulea ${ }^{1}$, Delia Vîrgă, Nicoleta Galben \\ Universitatea de Vest din Timişoara
}

\begin{abstract}
This study analyzed the factor structure and the psychometric properties of the Romanian version of the Work-Family Conflict Scale (Carlson, Kacmar \& Williams, 2000). Two studies were conducted $(N 1=275 ; N 2=424)$ for verifying, on one hand, factor structure and the psychometric properties of the scale, and, on the other hand, to evaluate the discriminative validity and relations with variables of interest. The results confirmed the six-factor structure of the original scale and also aspects of the discriminative validity. Relations with variables representing attitudinal and organizational consequences were analyzed and theoretical and practical implications were presented.
\end{abstract}

Keywords: work-family conflict, validity, job satisfaction, turnover intention, work engagement

\section{Résumé}

Cette étude visait à examiner la structure factorielle et les propriétés psychométriques de la version roumaine du travail-famille échelle de conflits (Carlson, Kacmar \& Williams, 2000). Ont mené deux études (N1=275; N2=424) pour vérifier la structure factorielle multidimensionnelle de l'échelle, la cohérence interne et d'évaluation de la validité et la relation avec les variables pertinentes. Les résultats ont confirmé la structure du barème de l'origine de six facteurs et aspects de la validité discriminative. Relations avec les variables de le type de conséquences comportementales et organisationnelles ont été analysées et les conséquences théoriques et pratiques ont été analysé.

Mots-clés: conflit travail-famille, la validation, la satisfaction au travail, l'intention de quitter, l'implication au travail

\section{Rezumat}

Acest studiu a urmărit verificarea structurii factoriale şi analiza proprietăţilor psihometrice ale versiunii in limba română a Scalei de Conflict Muncă-Familie (Carlson, Kacmar \& Williams, 2000). Au fost derulate două studii $(N 1=275 ; N 2=424)$ pentru a verifica, pe de o parte, structura factorială şi proprietăţile psihometrice ale versiunii în limba romană ale scalei şi, pe de alta parte, evaluarea validităţii discriminative a scalei şi relaţiilor cu variabile relevante. Rezultatele au confirmat structura de şase factori ai scalei originale, precum şi aspecte ale validităţii discriminativă. Au fost analizate relaţiile $\mathrm{cu}$ variabile de tip consecinţe atitudinale şi organizaţionale, fiind discutate implicaţiile teoretice şi practice.

Cuvinte cheie: conflict muncă-familie, validare, satisfacţia cu munca, intenţia de a părăsi organizaţia, implicarea în muncă

\footnotetext{
${ }^{1}$ Adresa de corespondenţă: csulea@socio.uvt.ro
} 


\section{Introducere}

Relaţia dintre domeniul muncii, activităţii profesionale şi cel al vieţii personale, şi mai specific, al familiei, a fost în mod constant în atenţia cercetătorilor, studiile din această arie intensificându-se în mod deosebit în ultima decadă. Această relaţie a fost studiată atât din perspectiva influenţei negative reciproce (de exemplu, conflictul muncăfamilie) (Netemeyer, Boles \& McMurrian, 1996; Carlson, Kacmar \& Williams, 2000), cât şi din perspectiva relaţiei pozitive (de exemplu, relaţia de dezvoltare reciprocă dintre muncă şi familie) (Carlson, Kacmar, Wayne \& Grzywacz, 2006).

Cercetătorii care au studiat interacţiunea domeniilor muncă-familie au făcut diferenţa între două direcţii ale conflictului dintre muncă şi familie: conflictul muncăfamilie (CMF) (engl. work-family conflict) şi conflictul familie-muncă (CFM) (engl. familywork conflict) (Netemeyer et al., 1996; Carlson et al., 2000). CFM apare atunci când activităţile legate de serviciu se intersectează cu responsabilităţile casnice (de exemplu, o persoană îşi aduce acasă ceea ce are de lucru acasă şi încearcă să rezolve sarcina în detrimentul timpului ce ar trebui alocat familiei), iar conflictul CFM apare atunci când responsabilităţile familiale împiedică activităţile de la serviciu (de exemplu, o persoană trebuie să-şi anuleze o întâlnire importantă deoarece copilul său s-a îmbolnăvit). Deşi sunt strâns legate între ele, sunt construcţii distincte din punct de vedere conceptual şi empiric.

Una dintre principalele teorii care stă la baza studiului relaţiei negative dintre domeniile muncă şi familie este cea a stresului legat de rol (cunoscută ca şi modelul Michigan Organization Stress Model, Kahn, Wolfe, Quinn, Snoek \& Rosenthal, 1964 apud Geurts \& Demerouti, 2003). Această perspectivă se bazează pe ideea că individul are resurse limitate de energie în vederea îndeplinirea multiplelor roluri, iar gestionarea acestora este dificilă şi în mod inevitabil implică tensiuni. Greenhaus şi Beutell (1985) au fost printre primii care au definit conflictul dintre domeniile vieţii profesionale şi vieţii personale, cea din urmă fiind înţeleasă mai degrabă în sensul familiei. Aceşti autori au definit conflictul între muncă şi familie ca fiind „o formă a conflictului inter-roluri în care presiunile din partea familiei şi cele din partea activităţii profesionale sunt reciproc incompatibile în anumite privinţe"
(Greenhaus \& Beutell, 1985, p. 77). Conflictul între muncă şi familie este o formă de conflict între roluri, unde rolurile de la muncă şi din alte domenii non - muncă necesită timp, energie şi implicare pentru a $\mathrm{fi}$ realizate în mod corespunzător, iar presiunea rolurilor de la muncă şi din familie sunt reciproc incompatibile. Această definiţie implică o relaţie bidirecţională între muncă şi viaţa de familie, ceea ce înseamnă că incompatibilitatea îşi poate găsi rădăcinile în oricare din cele două domenii. În mod mai specific, conflictul se poate baza pe acele cerinţe ale unui rol dintr-un domeniu (muncă sau familie) care să fie incompatibile cu cerinţele rolului din celălalt domeniu, din punct de vedere al timpului, tensiunii sau comportamentele solicitate. Astfel, rezultă trei forme ale conflictului (Greenhaus \& Beutell, 1985):

- Conflictul datorat timpului - unde presiunile dintr-un domeniu afectează îndeplinirea cerinţelor asociate celuilalt domeniu. Spre exemplu, situaţia în care numărul de ore petrecut de o persoană pentru activităţile profesionale limitează participarea la activităţi legate de familie

- Conflictul datorat tensiunii - unde aspecte precum oboseala, iritarea, anxietatea, depresia indică faptul că implicarea într-un rol asociat unui domeniu îngreunează îndeplinirea cerinţelor corespunzătoare rolului din celălat domeniu. Spre exemplu, situaţia în care iritarea experimentată la locul de muncă este transferată mai departe partenerului de viaţă sau copiilor, afectând energia sau disponibilitatea de care individul ar avea nevoie acasă.

- Conflictul datorat comportamentului care se referă la situaţiile unde tipare de comportamente asociate rolului dintr-un domeniu sunt incompatibile cu aşteptările de rol din celălalt domeniu. Spre exemplu, un comportament de tip autoritar de la locul de muncă poate fi incompatibil cu aşteptările legate de flexibilitate şi consideraţie de care ar avea nevoie membrii familiei.

În figura 1 este descris modelul multidimensional al relaţiei conflictuale dintre muncă şi familie. 


\begin{tabular}{|c|c|c|c|}
\hline \multirow{5}{*}{ 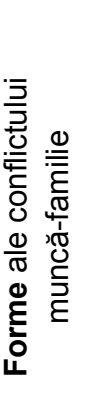 } & & \multicolumn{2}{|c|}{ Direcţii ale conflictului muncă-familie } \\
\hline & & Interferenţa muncii cu familia & Interferenţa familiei cu munca \\
\hline & Timp & $\begin{array}{l}\text { Interferenţa muncii cu familia bazată } \\
\text { pe timp }\end{array}$ & $\begin{array}{l}\text { Interferenţa familiei cu munca bazată pe } \\
\text { timp }\end{array}$ \\
\hline & Tensiune & $\begin{array}{l}\text { Interferenţa muncii cu familia bazată } \\
\text { pe tensiune }\end{array}$ & $\begin{array}{c}\text { Interferenţa familiei cu munca bazată pe } \\
\text { tensiune }\end{array}$ \\
\hline & Comportament & $\begin{array}{c}\text { Interferenţa muncii cu familia bazată } \\
\text { pe comportament }\end{array}$ & $\begin{array}{l}\text { Interferenţa familiei cu munca bazată pe } \\
\text { comportament }\end{array}$ \\
\hline
\end{tabular}

Figura 1. Dimensiuni ale conflictului între muncă şi familie (Sursa: Carlson, Kacmar \& Williams, 2000)

Studiile au demonstrat că cele trei forme de conflicte sunt concepte separate (deşi se leagă între ele) şi, de asemenea, au corelaţii diferite (Byron, 2005). Cu toate acestea, conflictul bazat pe comportament pare să aibă o validitate predictivă mai scăzută decât conflictul muncă - familie bazat pe timp şi tensiune, deoarece constructul -conflict muncă-familie bazat pe comportament - este mai dificil de măsurat (Kelloway, Gottlieb \& Barham, 1999). Dintre conflictul bazat pe timp şi cel bazat pe tensiune, cel de-al doilea explică într-o proporţie mai mare un nivel scăzut al satisfacţiei muncii, angajamentului organizaţional şi existenţa unor simptome fizice.

\section{Relaţia dintre muncă şi familie şi variabilele gen şi vârstă}

Genul constituie o caracteristică sociodemografică foarte des examinată în contextul cercetărilor din domeniul interfeţei muncăfamilie. S-au formulat, în timp, două categorii de ipoteze bazate pe aşteptările legate de rol. $\mathrm{Pe}$ de o parte, s-a presupus că, datorită responsabilităţilor familiale majore, factorii familiali parazitează munca în mai mare măsură la femei, decât la bărbaţi. lar factorii legaţi de muncă parazitează situaţiile familiale în mai mare măsură pentru bărbaţi decât pentru femei. Pe de altă parte, s-a considerat că femeile, în comparaţie cu bărbaţii, experimentează o influenţă negativă datorată muncii, datorită implicării lor în domeniul familial (Geurts \& Demerouti, 2003). Cercetările care au luat în considerare această variabilă au arătat că nu există diferenţe între bărbaţi şi femei în ceea ce priveşte experimentarea unei interacţiuni negative între muncă şi familie, în ambele direcţii (de exemplu, Grzywacz \& Marks, 2000; Kinnunen
\& Mauno, 1998). Efectele vârstei au fost sistematice în mai mică măsură. Această variabilă a fost fie corelată pozitiv cu conflictul între muncă şi familie (Burke \& Greenglass, 1999), fie s-a arătat că nu este relaţionată cu relaţia conflictuală între muncă şi familie (Kinnunen \& Mauno, 1998).

\section{Consecinţe ale conflictului muncă-familie}

Conflictul dintre muncă şi familie a fost analizat din perspectiva stresului legat de rol, fiind considerat o formă de conflict inter-rol în care rolurile asociate muncii şi familiei sunt considerate incompatibile. Numeroase studii au corelat stresorii legaţi de rol, în general, şi conflictul de rol, în particular, cu o varietate de atitudini legate de muncă. Cercetările au sugerat că relaţia conflictuală dintre muncă şi familie poate conduce la atitudini nefavorabile faţă de muncă, cum ar fi insatisfacţia cu munca, sau intenţii sporite de a părăsi organizaţia sau chiar părăsirea efectivă a acesteia (Spector, Allen, Poelmans, LaPierre, Cooper, O'Driscoll, Sanchez, Abarca, Alexandrova, Beham, Brough, Ferreiro, Fraile, Lu, Lu, Moreno-Velasquez, Pagon, Pitariu, Salamatov, Shima, Siminoni, Siu, WiderszalBazyl, 2007; Allen, Herst, Bruck \& Sutton, 2000). Se consideră că astfel de stresori conduc la emoţi negative care, mai departe, conduc la atitudini negative faţă de muncă (Spector et al., 2007). Frone, Yardley şi Markel (1997) au sugerat că există o legătură strânsă între direcţia conflictului şi perceperea insatisfacţiei astfel: CMF este strâns legat de insatisfacţia şi nemulţumirea familială, în timp ce CFM este asociat cu efectele negative ale muncii (de exemplu: intenţia de a părăsi organizaţia, aprecierea negativă a rolului muncii, stresul legat de rol). Cercetările au arătat, în general, o legătură semnificativă dintre un nivel ridicat al conflictului muncă- 
familie este legat de un nivel scăzut al satisfacţiei postului (Stepanski, 2002; Thomas \& Ganster, 1995; Rice, Frone \& McFarlin, 1992). Alte studii nu au găsit relaţii semnificative între aceste variabile (Balmforth \& Gardner, 2006; Kowalski, 1996).

O altă consecinţă importantă a relaţiei conflictuale între muncă şi familie este implicarea în muncă (engl. work-engagement), definită ca o stare afectiv-motivaţională, de împlinire legată de muncă, care este caracterizată de vigoare, dedicare şi absorbire (Schaufeli \& Bakker, 2004). Această dimensiune a fost studiată în mod extensiv prin modelul solicitări şi resurse ale muncii (engl. Job Demands-Resources Model; Demerouti, Bakker, Nachreiner \& Schaufeli, 2001). În general, studiile au arătat o legătură mai puternică între resurse şi implicarea în muncă, însă legătura dintre solicitări (cum este şi conflictul între muncă şi familie) şi implicarea în muncă este la fel de relevantă, chiar dacă procesul este unul indirect, solicitările postului reducând resursele de la locul de muncă şi astfel sunt legate negativ de implicarea în muncă a angajaţilor (Bakker, Hakanen, Demerouti \& Xanthopulou, 2007; Schaufeli \& Salanova, 2007). În mod specific, Montgomery, Peeters, Schaufeli, şi den Ouden (2003) au arătat că interferenţa negativă dintre familie şi muncă a fost corelată negativ cu una dintre dimensiunile implicării în muncă (vigoarea). Halbesleben (in press) a arătat în studiul său meta-analitic, că ambele forme ale relaţiei conflictuale dintre muncă şi familie au fost în general asociate negativ cu dimensiuni ale implicării în muncă, remarcând însă şi un rezultat neaşteptat, acela al relaţiei pozitive dintre conflictul muncă şi familie şi implicarea în muncă, în situaţiile în care s-a folosit un scor global al implicării în muncă.

\section{Obiective}

Scopul acestui studiu a fost de a analiza structura factorială şi proprietăţile psihometrice ale versiunii limba română a scalei multimensionale a conflictului dintre muncă şi familie. De asemenea, s-a urmărit şi evidenţierea aspectelor legate de validitatea de construct, discriminativă şi predictivă. Deşi în literatura de specialitate există mai multe scale care analizează conflictul sau interferenţa dintre muncă şi familie (Netemeyer et al., 1996) a fost aleasă scala lui Carlson et al. (2000) datorită complexităţii sale şi posibilităţii de a diferenţia atât între direcţiile conflictului, cât şi între formele sale specifice.

\section{Studiul 1}

Primul studiu are ca obiectiv verificarea structurii factoriale a instrumentului (ca dovadă a validităţii de construct a scalei), precum şi consistenţa sa internă (ca măsură a fidelităţii scalei).

\section{Metoda}

\section{Eşantionul}

În acest studiu au luat parte 275 de participanţi, angajaţi în diferite organizaţii, dintre care $52 \%$ bărbaţi, având media de vârstă 25.6 ani, $64 \%$ dintre ei fiind căsătoriţi, iar $73 \%$ au copii.

\section{Instrumente}

Versiunea în limba română a scalei conflict muncă-familie (precum cele ale instrumentelor folosite în Studiul 2) a fost dezvoltată folosind procedura standard de traducere şi retroversiune (Breslin, 1970): scalele au fost iniţial traduse în limba română de către un translator independent şi apoi această versiune a fost tradusă din nou în limba engleză de către un alt translator. Diferenţe minore în fiecare fază au fost rezolvate sub supervizarea autorilor.

Conflictul muncă-famile a fost măsurat cu Scala Conflictul Muncă-Familie (Carlson et al., 2000) care are 18 itemi, două direcţii (muncă-familie şi familie-muncă) şi trei dimensiuni pentru fiecare direcţie (timp, tensiune şi comportament). Cei 18 itemi măsoară ambele direcţii ale conflictului: conflictul muncă-familie (timp, de exemplu, „Munca mă reţine de la activităţile familiale mai mult decât mi-aş dori"; tensiune, de exemplu, „Când mă întorc de la serviciu adesea sunt prea istovit pentru a mai participa la activităţile/ responsabilităţile familiale"; comportament, de exemplu, "Comportamentele care mă face eficient la serviciu, nu mă ajută să fiu un părinte şi un soţ/soţie mai bun(ă)") şi conflictul familie-muncă (timp, de exemplu, „Timpul pe care-I dedic responsabilităţilor familiale adesea se interferează cu responsabilităţile de serviciu”; tensiune, de exemplu, „Datorită stresului de acasă, adesea sunt preocupat la lucru cu probleme familiale"; comportament, de exemplu, „Comportamentele care-mi sunt benefice acasă, la serviciu nu par să fie eficiente"). Răspunsurile au fost date pe o 
scală de tip Likert (1 = "dezacord puternic" la 7 = "acord puternic"). Un scor ridicat indică un nivel ridicat al conflictului între muncă şi familie.

\section{Analiza datelor}

Pentru testarea structurii factoriale a fost realizată analiză factorială confirmatorie, $\mathrm{cu}$ ajutorul AMOS 4.0. Analiza factorială confirmatorie a fost utilizată pentru a evalua modelul în şase factori, în care fiecare din cele 6 categorii de conflict sunt reprezentate separat. Pentru a face comparaţie, au fost testate diferite posibile modele de structurare a scalei.

Astfel, au fost testate mai multe modele alternative:

- un model care postula existenţa a 6 factori necorelaţi;
- un model care postula existenţa a 6 factori corelaţi;

- un model care postula existenţa a 6 factori şi a 3 supra-factori necorelaţi (Timp, Tensiune şi Comportament);

- un model care postula existenţa a 6 factori şi a 3 supra-factori corelaţi (Timp, Tensiune şi Comportament);

- un model care postula existenţa a 6 factori şi a unui supra-factor;

- un model care postula existenţa unui factor unic.

Tabelul 1 prezintă valorile indicilor de potrivire a modelelor, respectiv valorile lui $X^{2}$, GFI si RMSEA pentru fiecare din cele 6 modele.

Tabel 1. Indici de potrivire pentru cele 6 modele testate

\begin{tabular}{llllll}
\hline Model & $\mathrm{X}^{2}$ & & $\mathrm{X}^{2} / \mathrm{df}$ & GFI/AGFI & RMSEA \\
\hline 6 factori necorelaţi & $\mathrm{X}^{2}(135)=814.24$ & $\mathrm{p}<.001$ & 6.031 & $.736 / .666$ & .136 \\
6 factori corelaţi & $\mathrm{X}^{2}(120)=301.28$ & $\mathrm{p}<.001$ & 2.511 & $.895 / .850$ & .074 \\
3 supra-factori necorelaţi & $\mathrm{X}^{2}(132)=479.35$ & $\mathrm{p}<.001$ & 3.632 & $.841 / .793$ & .098 \\
3 supra-factori corelaţi & $\mathrm{X}^{2}(129)=376.41$ & $\mathrm{p}<.001$ & 2.918 & $.869 / .826$ & .084 \\
1 supra-factor & $\mathrm{X}^{2}(129)=421.66$ & $\mathrm{p}<.001$ & 3.269 & $.856 / .810$ & .091 \\
1 factor unic & $\mathrm{X}^{2}(135)=1406.089$ & $\mathrm{p}<.001$ & 10.415 & $.569 / .454$ & .185 \\
\hline
\end{tabular}

Rezultatele analizei indică faptul că modelul cu 6 factori corelaţi este cel mai potrivit pentru descrierea datelor obţinute. Acest rezultat este concordant şi cu structura identificată de autorii scalei în procesul de construcţie şi validare a ei (vezi Carlson et al., 2000).

\section{Consistența internă}

Consistenţa internă la nivel de subscală a fost calculată pe baza coeficienţilor alpha Cronbach. Aceştia au luat valori peste .80, conforme cu nivelul convenţional acceptat de .70 (Nunnaly, 1978), excepţie făcând scala de conflict familie-muncă bazată pe timp (valoare de .65, valabilă la limită). Astfel, subscala de conflict muncă-familie bazată pe timp: $\alpha=.87$, sub-scala conflictului muncă-familie bazat pe tensiune: $\alpha=.82$, sub-scala conflictului muncă-familie bazată pe comportament: $\alpha=81$. De asemenea, subscalele de pe dimensiunea conflictului familiemuncă s-au structurat astfel: sub-scala de conflict familie-muncă bazată pe timp: $\alpha=.65$, sub-scala de conflict familie-muncă bazată pe tensiune: $\alpha=.85$, iar sub-scala de conflict familie-muncă bazată pe comportament: $\alpha=$. 84.

\section{Studiul 2}

Al doilea studiu are ca obiectiv evaluarea validităţii discriminatorii a versiunii in limba română a chestionarului, analiza relaţiilor diferenţiale cu alte variabile (ca dovadă a validităţii predictive) şi verificarea diferenţelor de gen între sub-scale. Din literatura de specialitate au fost selectate variabile care sunt asociate cu cu conflictul dintre muncă şi familie (satisfacţia cu munca, intenţia de a părăsi organizaţia şi implicarea în muncă; Higgins, Duxbury \& Irving, 1992; Montgomery et al., 2003; Allen et al., 2000). În studiu au fost introduse şi variabile ce indică vechimea în muncă, în general, precum şi vechimea în 
organizaţie, urmărind analiza relaţiei dintre vechimea în muncă şi conflictul muncă-familie.

\section{Eşantionul}

Participanţii sunt 424 de angajaţi din diferite organizaţii, căsătoriţi, care au următoarele caracteristici: sunt $44.8 \%$ bărbaţi, au o vârstă medie de 38.8 ani, dintre care $13.7 \%$ nu au copii, $42.7 \%$ au un singur copil, iar $34.7 \%$ au trei copii. Dintre participanţi, $45.7 \%$ au studii superioare. Vechimea medie în muncă a participanţilor este de 14.4 ani iar vechimea medie în actuala organizaţie este de 6.5 ani.

\section{Instrumente}

Conflictul muncă-familie a fost măsurat cu Scala Conflictul Muncă-Familie (Carlson et al., 2000) (descrierea scalei este prezentată în studiul 1).

Satisfacţia cu munca a fost măsurată $\mathrm{cu}$ scala de trei itemi din Michigan Organizational Assessment Questionnaire (Camman, Fishman, Jenkins şi Klesh, 1979 apud O'Brien, 2004) ( „În general, îmi place să lucrez aici"). Răspunsurile au fost date pe o scală de tip Likert $(1=$ "dezacord total" la $7=$ "acord total"). Scorurile înalte indică o satisfacţie crescută. Consistenţa internă a scalei este de .86 .

Intenţia de părăsire a organizaţiei a fost măsurată folosind scala de trei itemi din Michigan Organizational Assessment Questionnaire (Camman, Fishman, Jenkins şi
Klesh, 1979 apud O'Brien, 2004) (de exemplu, „Este foarte probabil ca anul viitor să mă implic în căutarea unui loc de muncă"). Răspunsurile au fost date pe o scală de tip Likert $(1=$ "dezacord total" la 7 = "acord total"). Scorurile înalte indică o intenţie crescută de a părăsi organizaţia. Consistenţa internă a scalei este de 0.83 .

Implicarea în muncă a fost măsurată folosind Scala Utrecht a implicării în muncă cu 9 itemi (UWES 9; Schaufeli, Bakker, \& Salanova, 2006) ce cuprinde trei dimensiuni: Vigoare (3 itemi; de exemplu, "La locul de muncă, simt că explodez de energie"), Dedicare (3 itemi; de exemplu, Sunt entuziasmat(ă) de locul meu de muncă) şi Absorbire ( 3 itemi; de exemplu, Sunt foarte implicat(ă) în munca mea). Scala a fost adaptată în România de către Vîrgă, Zaborilă, Sulea şi Maricuţoiu (2009), fiind considerată un instrument valid şi cu coeficienţi de consistenţă internă variind între .84 şi .92 . Răspunsurile au fost date pe 0 scală de tip Likert $(0=$ "niciodată" la 6 = "întotdeauna / în fiecare zi"). Consistenţa internă a scalei în acest studiu este de .89 .

\section{Rezultate}

\section{Analize descriptive}

Pentru a ilustra variabilitatea scorurilor la nivelul fiecărei dimensiuni, prezentam în tabelul 2 mediile şi abaterile standard pentru fiecare dintre dimensiunile vizate.

Tabel 2. Statistici descriptive pentru cele şase dimensiuni ale scalei şi variabilele conexe

\begin{tabular}{lrrr}
\hline Interacţiunea dintre & N & Media & Abaterea standard \\
\hline 1. muncă şi familie bazată pe timp (CMF T) & 424 & 8.0449 & 3.32951 \\
2. familie şi munca bazată pe timp (CFM T1) & 424 & 6.7807 & 2.44785 \\
3. munca si familie bazată pe tensiune (CMF Tens) & 424 & 8.2075 & 2.87967 \\
4. familie şi munca bazată pe tensiune (CFM Tens1) & 424 & 7.2783 & 2.66186 \\
5. munca si familie bazată pe comportament (CMF Comp) & 424 & 6.9882 & 2.78672 \\
6. familie şi munca bazată pe comportament (CFM Comp1) & 424 & 7.1321 & 2.59049 \\
Intenţia de a părăsi organizaţia & 424 & 10.2689 & 4.7801 \\
Implicare în muncă - Scala Vigoare & 424 & 8.7594 & 3.2751 \\
Implicare în muncă - Scala Dedicare & 424 & 9.5377 & 3.5905 \\
Implicare in muncă - Scala Absorbire & 424 & 10.0849 & 3.3123 \\
Implicare în muncă & 424 & 27.5920 & 8.7773 \\
Satisfacţia în muncă & 424 & 10.6014 & 4.1830 \\
\hline
\end{tabular}




\section{Validitatea discriminativă a dimensiunilor scalei}

Validitatea discriminativă a fost apreciată pe baza corelaţiilor inter-scale. Corelaţiile celor şase factori, respectiv a celor şase sub-scale sunt prezentate în tabelul 3 şi iau valori în medie, între .27 şi .60. Doar două corelaţii au valori sub .25. Astfel, există dovezi care susţin validitatea discriminativă.

Tabel 3. Validitatea discriminativă a celor şase dimensiuni ale scalei

\begin{tabular}{|c|c|c|c|c|c|c|}
\hline Interacţiunea dintre & 1 & 2 & 3 & 4 & 5 & 6 \\
\hline 1. muncă şi familie bazată pe timp (CMF T) & -- & & & & & \\
\hline 2. familie şi munca bazată pe timp (CFM T1) & .520 & -- & & & & \\
\hline 3. munca si familie bazată pe tensiune (CMF Tens) & .489 & .443 & -- & & & \\
\hline 4. familie şi munca bazată pe tensiune (CFM Tens1) & .277 & .427 & .489 & -- & & \\
\hline 5. munca si familie bazată pe comportament (CMF Comp) & .452 & .312 & .371 & .101 & -- & \\
\hline 6. familie şi munca bazată pe comportament (CFM Comp1) & .477 & .339 & .438 & .201 & .601 & -- \\
\hline
\end{tabular}

Notă: $N=424$. Toate corelaţiile sunt semnificative la $p<.05$.

\section{Diferențe de gen}

Pentru a identifica diferenţele de gen, am realizat teste $t$ (Student) între participanţii de gen masculin şi feminin, pentru fiecare dintre cele 6 dimensiuni ale conflictului muncăfamilie. Pentru trei dintre cele şase dimensiuni au fost identificate diferenţe semnificative (Tabelul 4). În mod specific, s-a arătat ca femeile experimentează în mai mare măsură conflictul muncă-familie bazat pe comportament şi conflictul familie-muncă bazat pe tensiune. Adică, femeile nu pot prelua strategiile comportamentale de succes la pe care le adoptă la serviciu pentru a rezolva problemele din familie, iar tensiunile din viaţa personală tind să genereze stări conflictuale la serviciu. Bărbaţii experimentează, în mai mare măsură, conflictul muncă-familie bazat pe timp. Adică, îşi petrec prea mult timp la serviciu şi nu mai au resurse de timp pentru activităţile dedicate familiei. Se poate ca aceste rezultate să fie diferite de cercetările anterioare legate de diferenţele între bărbaţi şi femei (Eagle, Miles \& Icenogle, 1997), dar sunt consistente cu rezultate obţinute de autorii scalei (Carlson et al., 2000). Astfel, modul în care se măsoară constructul induce diferenţele observate la nivel de rezultate.

Tabel 4. Diferenţe între bărbaţi şi femei

\begin{tabular}{|c|c|c|c|c|}
\hline \multirow[b]{2}{*}{ Interacţiunea dintre } & \multirow[b]{2}{*}{$\begin{array}{l}\text { Media } \\
\text { Bărbaţi }\end{array}$} & \multirow[b]{2}{*}{$\begin{array}{l}\text { Media } \\
\text { Femei }\end{array}$} & \multicolumn{2}{|c|}{ Testul t } \\
\hline & & & $t$ & $p$ \\
\hline 1. muncă şi familie bazată pe timp (CMF T) & 8.58 & 7.60 & 3.04 & 0.003 \\
\hline 2. familie şi muncă bazată pe timp (CFM T1) & 6.89 & 6.87 & -0.56 & 0.95 \\
\hline 3. muncă şi familie bazată pe tensiune (CMF Tens) & 8.74 & 8.33 & -1.65 & 0.10 \\
\hline 4. familie şi muncă bazată pe tensiune (CFM Tens1) & 6.92 & 7.56 & -2.50 & 0.01 \\
\hline 5. muncă şi familie bazată pe comportament (CMF Comp) & 6.60 & 7.20 & -2.56 & 0.01 \\
\hline 6. familie şi muncă bazată pe comportament (CFM Comp1) & 6.95 & 7.27 & -1.24 & 0.21 \\
\hline
\end{tabular}




\section{Relații diferenţiale}

$\mathrm{Au}$ fost examinate relaţile dintre diferite variabile şi dimensiunile conflictului muncă-familie, conform argumentării teoretice, pe baza studiilor anterioare. În primul rând, am realizat corelaţiile dintre dimensiunile conflictului muncă-familie şi câteva variabile demografice, respectiv vechimea în muncă, vechimea în organizaţie, numărul de copii şi vârsta.

Tabel 5. Date privind validitatea Scalei de conflict muncă-familie (I)

\begin{tabular}{lcccc}
\hline Interacţiunea dintre & $\begin{array}{l}\text { Vechimea } \\
\text { în muncă }\end{array}$ & $\begin{array}{c}\text { Vechimea } \\
\text { în } \\
\text { organizaţie }\end{array}$ & $\begin{array}{c}\text { Nr. } \\
\text { copii }\end{array}$ & Vârsta \\
\hline 1. muncă şi familie bazată pe timp (CMF T) & .165 & .235 & -.109 & 024 \\
2. familie şi muncă bazată pe timp (CFM T1) & .148 & .193 & -.035 & .011 \\
3. muncă şi familie bazată pe tensiune (CMF Tens) & -.019 & .251 & .083 & .064 \\
4. familie şi muncă bazată pe tensiune (CFM Tens1) & -.094 & .065 & .029 & -.078 \\
5. muncă şi familie bazată pe comportament (CMF Comp) & .199 & .199 & .008 & .042 \\
6. familie şi muncă bazată pe comportament (CFM Comp1) & .110 & .185 & -.016 & .020 \\
\hline
\end{tabular}

Notă. $N=424$. Corelaţiile cu bold sunt semnificative la $p \leq .05$

Corelaţiile din tabelul 5 relevă corelaţii pozitive semnificative între ambele direcţii şi diversele forme ale conflictului şi vechimea în muncă şi organizaţie. Numărul copiilor este asociat negativ doar cu forma bazată pe timp a conflictului muncă-familie iar cu vârsta nu există legături semnificative.

$\mathrm{Au}$ fost examinate şi relaţiile dintre dimensiunile conflictului muncă-familie şi variabilele care sunt considerate consecinţe ale acestui tip de conflict. Astfel, variabilele luate în analiză în cadrul acestui studiu au fost: implicarea în muncă, satisfacţia cu munca şi intenţia de a părăsi organizaţia. Conflictul de tip muncă-familie bazat pe tensiune este corelat pozitiv cu măsura globală a implicării în muncă, dar şi cu dimensiunile specifice, cum este vigoarea. Toate cele trei forme ale conflictului de tip familie-muncă sunt corelate pozitiv cu dimensiunea globală a implicării în muncă, dar şi cu anumite dimensiuni specifice. Aceste asocieri pozitive între conflictul dintre muncă şi familie, sunt într-o anumită măsură surprinzătoare, având în vedere că relaţia conflictuală dintre muncă şi familie este considerată o solicitare, conform modelului JDR (Demerouti et al., 2001), iar solicitările de la locul de muncă sunt, în general, asociate negativ cu implicarea în muncă (Montgomery et al., 2003).

Tabel 6. Date privind validitatea Scalei de conflict muncă-familie (continuare - II)

\begin{tabular}{|c|c|c|c|c|c|c|}
\hline Interacţiunea dintre & $\begin{array}{l}\text { Intenţia de } \\
\text { a părăsi } \\
\text { organizaţia }\end{array}$ & $\begin{array}{l}\text { Implicare } \\
\text { în muncă } \\
\text { - Scala } \\
\text { Vigoare }\end{array}$ & $\begin{array}{l}\text { Implicare } \\
\text { în muncă } \\
\text { - Scala } \\
\text { Dedicare }\end{array}$ & $\begin{array}{l}\text { Implicare } \\
\text { în muncă - } \\
\text { Scala } \\
\text { Absorbire }\end{array}$ & $\begin{array}{l}\text { Implicare } \\
\text { în muncă } \\
\text { - Scor } \\
\text { total }\end{array}$ & $\begin{array}{l}\text { Satisfacţie } \\
\text { în muncă }\end{array}$ \\
\hline $\begin{array}{l}\text { 1. munca si familie bazată pe } \\
\text { timp (CMF T) }\end{array}$ & -.122 & .048 & .066 & .008 & .062 & .032 \\
\hline $\begin{array}{l}\text { 2. familie şi munca bazată pe } \\
\text { timp (CFM T1) }\end{array}$ & -.266 & .146 & .154 & -.026 & .164 & .130 \\
\hline $\begin{array}{l}\text { 3. munca si familie bazată pe } \\
\text { tensiune (CMF Tens) }\end{array}$ & -.110 & .125 & .070 & .004 & .134 & -.064 \\
\hline $\begin{array}{l}\text { 4. familie şi munca bazată pe } \\
\text { tensiune (CFM Tens1) }\end{array}$ & -.171 & .172 & .136 & .017 & .190 & .075 \\
\hline $\begin{array}{l}\text { 5. munca si familie bazată pe } \\
\text { comportament (CMF Comp) }\end{array}$ & -.089 & -.036 & .008 & -.065 & .031 & -.079 \\
\hline $\begin{array}{l}\text { 6. familie şi munca bazată pe } \\
\text { comportament (CFM Comp1) }\end{array}$ & -.080 & -.005 & -.004 & -.048 & .350 & -.054 \\
\hline
\end{tabular}

Notă. $N=424$. Corelaţiile cu bold sunt semnificative la $p \leq .05$ 
Cercetările anterioare însă au arătat rezultate contradictorii (vezi Halbesleben, in press). Halbesleben (in press) a arătat în meta-analiza sa că există corelaţii negative între dimensiunile specifice ale implicării în muncă şi conflictul dintre muncă şi familie, însă pozitive între măsura globală a implicării în muncă şi conflictul dintre muncă şi familie. Legăturile pozitive între implicarea în muncă şi conflictul dintre muncă şi familie pot fi bazate pe logica conform căreia persoanele decicate muncii şi care investes energie şi concentrare în acesată zonă pot ajunge să experimenteze o stare conflictuală mai intensă (de exemplu, fiind implicaţi şi pasionaţi de munca pe care o fac, persoanele pot aloca mai puţină atenţie sau energie activităţilor din sfera familiei). Practic, cu cât angajaţii sunt mai implicaţi în munca lor, cu atât mai mult ei pot resimţi lipsa de timp sau disponibilitate pentru problemele familiale şi pot acumula tensiune în legătură cu problemele personale nerezolvate.

Legătura dintre satisfacţia în muncă şi conflictul muncă-familie s-a identificat, în cadrul studiului de faţă, doar în cazul conflictului familie-muncă bazat pe timp, fiind posibil ca timpul investit pentru obţinerea satisfacţiilor profesionale să fie în detrimentul celui petrecut în familie. Relaţii nesemnificative între satisfacţia cu munca şi conflictul muncăfamilie au fost relevate şi în studii anterioare (Balmforth \& Gardner, 2006). În ceea ce priveşte intenţia de a părăsi organizaţia, s-au identificat corelaţii negative între ambele direcţii ale conflictului şi formele bazate pe timp sau tensiune. Aceste rezultate sunt surprinzătoare, având în vedere corelaţiile pozitive identificate în studii anterioare (Allen et al., 2000). Acest aspect poate fi explicat luând în considerare situaţia economică şi socială actuală, în general în lume şi specific în România, când opţiunile legate de găsirea unui nou loc de muncă, sunt foarte limitate, iar renunţarea la actualul loc de muncă, chiar dacă presupune stres şi conflict între rolurile individului, nu este percepută ca o opţiune cu rol adaptativ. Perceperea conflictul este mai degrabă asociată cu intenţia de a rămâne în organizaţie şi de a găsi alte modalităţi adaptative pentru diminuarea disconfortului asociat conflictului.

\section{Discuţii}

Cercetarea de faţă şi-a propus, testarea structurii factoriale şi analiza proprietăţilor psihometrice ale versiunii în limba română a scalei de conflict muncă-familie, precum şi analiza aspectelor legate de diverse tipuri de validitate, bazându-se pe o abordare multidimensională a acestui construct. În cadrul testării structurii factoriale, dintre modele testate, şi-a dovedit viabilitatea modelul în şase factori, conform structurii originale a scalei. Fiecare dintre sub-scalele chestionarului au demonstrat că au o bună consistenţă internă şi validitate discriminativă. Pe de alta parte, dovezile vizând validitatea predictivă potenţială a scalei, pe un eşantion din populaţia românească, a fost stabilite prin corelaţii cu variabile relevante de tip consecinţe atitudinale şi organizaţionale (implicare în muncă, satisfacţia cu munca, precum şi intenţia de a părăsi organizaţia), dar şi cu date de tip demografic (cum ar fi: vechimea în muncă, vechimea în organizaţie, vârsta şi numărul de copii). Acest studiu contină linia cercetărilor începute şi în zona estică (Spector et al., 2007), ceea ce reprezintă un pas important în studiul acestor aspecte, având în vedere faptul că dimensiunile culturale şi sociale pot afecta dinamica relaţională a conflictului dintre muncă şi familie şi diferite tipuri de consecinţe. Dacă într-un mediu stabil economic, intenţia de a părăsi organizaţia este văzută ca o opţiune adaptativă pentru individ, de reducere a stresului şi disconfortului asociat interferenţei negative dintre muncă şi familie, în medii economice instabile, cum este cel din prezent, mai ales in România, individul este mai degrabă preocupat de menţinerea locului de muncă, chiar dacă activităţile asociate rolului profesional afectează negativ viaţa personală. Faptul că implicarea în muncă a angajatului este asociată pozitiv cu conflictul muncăfamilie poate avea la bază argumentaţia conform căreia preocuparea angajatului pentru muncă şi energia investită în acest domeniu, afectează disponibilitatea acestuia pentru domenii aparţinând vieţii sale personale.

Aprofundarea înţelegerii implicaţiilor şi mecanismelor pe care se bazează aceste relaţii şi luare în considerare a factorilor sociali şi economici reprezintă provocări importante ale cercetătorilor şi practicienilor din domeniu, datorită implicaţiilor pe care acestea le au pentru confortul psihologic al angajaţilor şi consecinţele în plan organizaţional. Utilizarea ulterioară a scalei poate contribui la înţelegerea mai complexă a diferitelor dimensiuni ale conflictului dintre muncă şi familie cu diferite atitudini şi comportamente din mediul organizaţional. 
Studiul nostru prezintă şi anumite limite. În primul rând, acest demers de validare s-a realizat doar pe două eşantioane. Ar fi necesară o validare specifică diferitelor tipuri de organizaţii şi diferitelor tipuri de ocupaţii profesionale. În al doilea rând, pentru testarea validităţii predictive a scalei am introdus în studiu doar trei variabile, considerate potenţiale consecinţe ale conflictului muncăfamilie, şi patru variabile demografice. Viitoarele cercetări ar trebui să includă şi alte variabile care sunt legate de dimensiunile conflictului muncă-familie, atât la nivel de predictori, cât şi la nivel de consecinţe.

$\mathrm{Cu}$ toate aceste limite, considerăm importantă şi necesară continuarea cercetărilor conflictului muncă-familie, în special la nivel comportamental, pentru a-I înţelege şi a-l putea evalua. Totuşi, incapacitatea individului de a-şi modifica comportamentul de la un rol la altul, subliniază existenţa conflictului. În final, considerăm necesară o analiză amănunţită a legăturilor celor şase dimensiuni ale conflictului muncă-familie cu alte variabile.

\section{Bibliografie}

Allen, T., D., Herst, D., E., L., Bruck, C., S., Sutton, M. (2000). Consequences Associated With Work-to-Family Conflict: A Review and Agenda for Future Research. Journal of Occupational Health Psychology, 5 (2), 278308.

Bakker, A. B., Hakanen, J.J. Demerouti, E. \& Xanthopoulou, D. (2007). Job resources boost work engagement, particularly when job demands are high. Journal of Educational Psychology, 99 (2), 274-284.

Balmforth, K. \& Gardner, D. (2006). Conflict and Facilitation between Work and Family: Realizing the Outcomes for Organizations. New Zeeland Journal of Psychology, 35(2) 2006.

Breslin, R.W. (1970). Back-translation for crosscultural research. Cross-cultural psychology, $1,185-216$.

Byron, K. (2005). A meta-analytic review of workfamily conflict and its antecedents. Journal of Vocational Behavior, 67, 169-198.

Burke, R.J., \& Greenglass, E.R. (1999). Work-family congruence and work family concerns among nursing staff. CNJL, 12 (2), 21-30.

Carlson, D.S., Kacmar, K.M., Wayne, J.H., \& Grzywacz, J.G. (2006). Measuring the positive side of work-family interface: Development and validation of a work-family enrichment scale. Journal of Vocational Behavior, 68, 138-164

Carlson, D., S., Kacmar, K., M., \& Williams, L. J. (2000). Construction and Initial Validation of a Multidimensional Measure of Work-Family Conflict. Journal of Vocational Behavior, 56, 249-276.

Demerouti, E., Bakker, A. B., Nachreiner, F., \& Schaufeli, W.B. (2001). The Job DemandsResources Model of Burnout. Journal of Applied Psychology, 86, 499-512.

Eagle, B. W., Miles, E. W., \& Icenogle, M. L. (1997). Interrole conflicts and permeability of work and family domains: Are there gender differences? Journal of Vocational Behavior, 50, 168-184.

Frone, M.R., Yardley, J.K., Markel, K.S. (1997). Developing and testing an integrative model of the work-family interface. Journal of Vocational Behavior, 50, 145-167.

Greenhaus, J.H., \& Beutell, N.J. (1985). Sources of conflict between work and family roles. Academy of Management Review, 10 (1), 7688.

Geurts, S. A. E., \& Demerouti, E. (2003). Work/nonwork interface: A review of theories and findings. In M. J. Schabracq, J. A. M. Winnubst, \& C. L. Cooper (Eds.), The handbook of work and health psychology (pp. 279-312). New York: Wiley.

Grzywacz, J.G., \& Marks, N. (2000). Reconceptualizing the work-family interface: An ecological perspective on the correlates of positive and negative spillover between work and family. Journal of Occupational Health Psychology, 5 (1), 111-126.

Halbesleben, J.R.B. (in press). A meta-analysis of work engagement: relationships woth burnout, demands and consequences. In A. B. Bakker şi M.P. Leiter (coord.). Work engagement: $A$ handbook of essential theory and research. UK: Psychology Press.

Higgins, C.A., Duxbury, L.E., \& Irving, R.H. (1992). Work-family conflict in the dual-career family. Organizational Behavior and Human Decision Processes, 51, 51-75.

Kelloway, E. K., Gottlieb, B. H., \& Barham, L. J. (1999). Variables Affecting Managers' Willingness to Grant Alternative Work Arrangements. Journal of Social Psychology, 138 (3), 291-302.

Kinnunen, U., \& Mauno, S. (1998). Antecedents and outcomes of work-family conflict among employed women and men in Finland. Human Relations, 51 (2), 157-177.

Kowalski, K.B. (1997). A model of the antecedents and outcomes of work-family conflict as 
moderated by social support. Lucrare de disertaţie nepublicată. University of Rhode Island.

Montgomery, A.J., Peeters, M.C.W., Schaufeli, W.B., \& den Ouden, M. (2003). Work-home interference among newspaper managers: its relationship with burnout and engagement. Anxiety, Stress and Coping, 16 (2), 195-211

Netemeyer, R.G., Boles, J.S., \& McMurrian, R. (1996). Development and validation of workfamily conflict and family-work conflict scales. Journal of Applied Psychology, 81 (4), 400410.

Nunnally, J. C. (1978). Psychometric theory (2nd ed.). New York: McGraw-Hill.

O'Brien, K. (2004). Self-determination theory and locus of control as antecedents of voluntary workplace behaviors. Teză doctorală nepublicată. University of South Florida.

Rice, R.W., Frone, M. R., \& McFarlin, D. B. (1992). Work-nonwork conflict and the perceived quality of life. Journal of Organizational Behaviour, 13, 155-168.

Schaufeli, W. B., \& Salanova, M. (2007). Work engagement: An emerging psychological concept and its implications for organizations. In S. W. Gilliland, D. D. Steiner, D. P. Skarlicki (Eds.). Managing social and ethical issues in organizations (pp. 135-177). Charlotte, NC: Information Age Publishing.

Schaufeli, W.B., Bakker, A.B., \& Salanova, M. (2006). The Measurement of Work Engagement with a short questionnaire: A
Cross-National Study. Educational and Psychological Measurement, 66, 701-716.

Schaufeli, W.B., \& Bakker, A.B. (2004). Job demands, job resources, and their relationship with burnout and engagement: a multi-sample study. Journal of Organizational Behavior, 25, 293-315.

Spector, P.E., Allen, T.D., Poelmans, S.A.Y., LaPierre, L.M., Cooper, C.L., O'Driscoll, M., Sanchez, J.I., Abarca, N., Alexandrova, M., Beham, B., Brough, P., Ferreiro, P., Fraile, G., Lu, C.Q., Lu, L., Moreno-Velasquez, I., Pagon, M., Pitariu, H., Salamatov, V., Shima, S., Siminoni, A.S., Siu, O.L., \& WiderszalBazyl, M. (2007). Cross-national differences in relationships of work demands, job satisfaction, and turnover intentions with work-family conflict. Personnel Psychology, 60 (4), 805-835.

Stepanski, K.M. (2002). Work-family conflict theories: Integration and model development. Lucrare de disertaţie nepublicată. Wayne State University.

Thomas, L. T., Ganster, D. C. (1995). Impact of family-supportive work variables on on workfamily conflict and strain: A control perspective. Journal of Applied Psychology, 80, 6-15.

Vîrgă, D., Zaborilă, C., Sulea, C., \& Maricuţoiu, L. (2009). Adaptarea în limba română a Scalei Utrecht de măsurare a implicării în muncă: examinarea validităţii şi a fidelităţii. Psihologia Resurselor Umane, 7 (1), 58-74. 